Springer Series in Design and Innovation 9

Daniel Raposo - Joãó Neves. José Silva. Luísa Correia Castilho - Rui Dias Editors

Advances in Design, Music and Arts

7th Meeting of Research in Music, Arts and Design, EIMAD 2020, May 14-15, 2020

Springer 
Design and Society

Arts' Meeting/Melting. From a Strategy for Recovering Sicilian Abandoned Buildings, to a New Artistic Process . . . . . . . . . . . . . . 475 Santi Centineo

Ageing in Place: A Design (er) Challenge

Cristina Caramelo Gomes

Chaos and Innovation in Design for Disaster Resilience.

Lara Leite Barbosa

Communication Design Within Social Innovation

Ana Melo and Marco Neves

Design and Culture in the Making of Happiness

Maria Luísa Costa and Gonçalo Estêvão

Design and Knowledge: Creative Thinking for a Knowledge-Based

Society and Policy

Marlene Ribeiro and Francisco Providência

Current Issues in Design Policies: Balancing Tensions .

Rui Monteiro, Bruno Giesteira, Anne Boddington,

and Cristina Farinha

Guidelines to Help Developing Projects and Activities with Individuals

with Special Needs . . . . . . . . . . . . . . . . . . . . . . . . . . . 579

Mafalda Sofia Almeida

Point of View on Dialectics in the Commercial Scenario of the Circular Economy

Caio Vitoriano Carvalho

This One or that One? Certification Marks in the Purchasing

and Consumption Decision Process of Brazilians

Diego Normandi, Cibele Taralli, and Franklin de Sousa Torres

Music, Musicology and Music Education

Auditory Alarms Design Tool: Spectral Masking Estimation

Based on a Psychoacoustic Model

Frederico Pereira, Rui Marques, and Joana Vieria

Epistemic Virtues as Theoretical Bridges Between Design

and Arnold Schoenberg's String Quartet op. 7

Washington Morales Maciel

The Policoral Mass of Las Palmas de Gran Canaria by Manuel de Tavares

Luísa Correia Castilho 
Teaching Music History in Italian Licei Musicali: An Analysis of the Current Situation and Some Pedagogical Principles. . . . . . . . . . 667 Paolo Sullo

Rudimental: A Musical Practice Tool.

Nuno João Casteleira, Luísa Correia Castilho, Arminda Guerra Lopes, and Luís Pereira

AM-I-BLUES: An Interactive Digital Music Instrument for Guiding Novice Pianist in the Improvisation of Jazz Melodies Isabela Corintha, Luís Outeiro, Rui Dias, and Gilberto Bernardes 


\title{
Rudimental: A Musical Practice Tool
}

\author{
Nuno João Casteleira, Luísa Correia Castilho, Arminda Guerra Lopes, \\ and Luís Pereira
}

\begin{abstract}
Following the experience of musical teaching, researchers found that often students don't know how to apply study strategies and be self-proficient. A group of researchers developed an online platform, which intends to optimize the students' time when playing musical instruments. The platform allows a teacher to monitor students' work, through the use of data logged during a set of classes and practice sessions. This paper presents the design process and the implications of the tool implementation. The results obtained before and after the use of this platform, by a group of students, are described. Findings show that this platform's use as a pedagogical practice tool, permitted students to improve their instrumental practice.
\end{abstract}

Keywords Music education · Musical study $\cdot$ Communication and information technologies

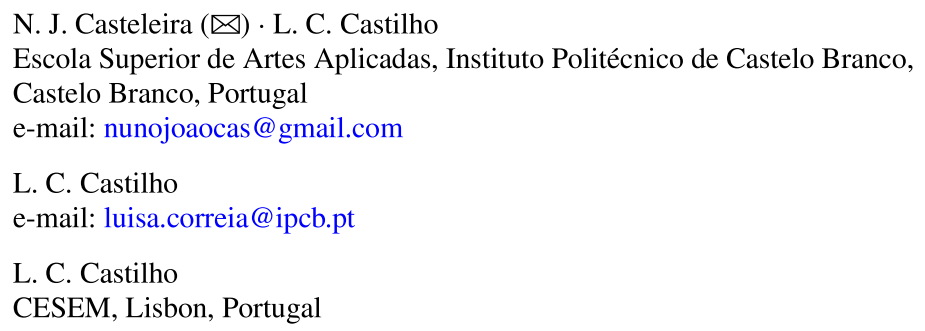

A. G. Lopes - L. Pereira

Escola Superior de Tecnologia, Instituto Politécnico de Castelo Branco, Castelo Branco, Portugal e-mail: aglopes@ipcb.pt

L. Pereira

e-mail: luispereira@ipcb.pt

A. G. Lopes

ITI/LARSyS, Castelo Branco, Portugal

(C) The Editor(s) (if applicable) and The Author(s), under exclusive license

D. Raposo et al. (eds.), Advances in Design, Music and Arts, Springer Series in Design and Innovation 9, https://doi.org/10.1007/978-3-030-55700-3_47 